ARAÚJO, TH; PÁDUA, JG; SPOTO, MHF; ORTIZ, VDG; MARGOSSIAN, PL; DIAS, CTS; MELO, PCT. 2016. Productivity and quality of potato cultivars for processing as shoestrings and chips. Horticultura Brasileira 34: 554-560. DOI - http://dx.doi.org/10.1590/S0102-053620160415

\title{
Productivity and quality of potato cultivars for processing as shoestrings and chips
}

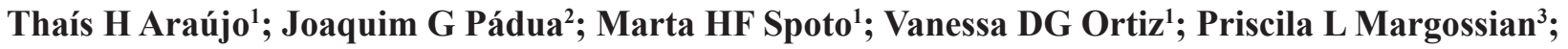 Carlos TS Dias'; Paulo CT Melo'}

'Escola Superior de Agricultura Luiz de Queiroz (ESALQ-USP), Piracicaba-SP, Brasil; tharaujo@usp.br; martaspoto@usp.br; vanessa_ groppo@yahoo.com.br; paulomelo@usp.br; ctsdias@usp.br; ${ }^{2}$ Empresa de Pesquisa Agropecuária de Minas Gerais (EPAMIG), Pouso Alegre-MG, Brasil; padua2008@gmail.com; ${ }^{3}$ Margossian Seeds Ltda., Indaiatuba-SP, Brasil; priscila.margossian@gmail.com

\begin{abstract}
Brazilian market of potato processing has presented expressive development in recent years. However, its expansion is constrained by raw material supply suitable for industrial processing. Selection of adequate cultivars contributes to final product cost reduction as well as its yield and quality improvement. The research aimed to study tuber yield and evaluate its frying potential for shoestrings and chips, of potato cultivars recently introduced in Brazil. Nine potato cultivars (Arizona, Caruso, Destiny, Excelence, Saviola, Agata, Almera, Fontane and Markies) were assessed in an experiment carried out between January and May, 2013, in South-West region of Minas Gerais State, Brazil. 'Arizona' and 'Caruso' cultivars exhibited superior productive potential and along with 'Markies' the highest production of marketable tubers. 'Caruso' and 'Destiny' produced more than $20 \%$ of dry matter and the lowest reducing sugar levels. 'Caruso' exhibited the highest frying yield in both processing shapes and absorbed less fat as shoestring. 'Destiny' absorbed less fat when processed as chips. 'Excelence' presented intermediary performance for every evaluated attribute. 'Caruso', 'Destiny', and 'Excelence' produced chips with appropriate color for market. Among the assessed cultivars, 'Caruso', 'Destiny', and 'Excelence' were the most promising. These cultivars demonstrated appropriate processing ability in the shape of shoestrings. 'Destiny' could also be indicated to be processed as chips.
\end{abstract}

Keywords: Solanum tuberosum, dry matter content, reducing sugars, oil uptake, chips color, industrial yield.

\section{RESUMO}

Produtividade e qualidade de cultivares de batata para industrialização na forma de batata-palha e chips

O mercado brasileiro de processamento de batata tem mostrado expressivo crescimento nos últimos anos. No entanto, sua expansão é condicionada pelo suprimento de matéria-prima adequada ao processamento industrial. A escolha correta da cultivar contribui para a redução do custo de produção e para o aumento do rendimento e da qualidade do produto final. $\mathrm{O}$ objetivo da pesquisa foi estudar a eficiência produtiva de cultivares de batata recém introduzidas no Brasil e a qualidade para fritura na forma de batata-palha e chips. Foram avaliadas nove cultivares de batata (Arizona, Caruso, Destiny, Excelence, Saviola, Agata, Almera, Fontane e Markies) em ensaio conduzido entre janeiro e maio de 2013, na região sudoeste de Minas Gerais. As cultivares Arizona e Caruso exibiram maior potencial produtivo e, juntamente com 'Markies', a maior produção de tubérculos comerciáveis. 'Caruso' e 'Destiny' produziram mais de 20\% de massa seca e baixos teores de açúcares redutores. 'Caruso' mostrou o maior rendimento de fritura em ambas as formas de processamento e absorveu menos gordura na forma de palha. 'Destiny' absorveu menos gordura como chips. 'Excelence' apresentou desempenho intermediário em todos os atributos avaliados. 'Caruso', 'Destiny' e 'Excelence' produziram chips com cor adequada ao mercado. Entre as cultivares avaliadas, 'Caruso', 'Destiny' e 'Excelence' foram as mais promissoras e se apresentaram apropriadas ao processamento na forma de batata-palha e 'Destiny' pode ser indicada também para o processamento de chips.

Palavras-chave: Solanum tuberosum, massa seca, açúcares redutores, absorção de gordura, cor das fritas, rendimento industrial.

(Recebido para publicação em 10 de março de 2015; aceito em 26 de julho de 2016) (Received on March 10, 2015; accepted on July 26, 2016)

$\mathrm{S}$ ince late $90 \mathrm{~s}$, there were significant changes in Brazilian potato crops resulting in yield increase. These alterations are related with several factors, such as innovative technologies, properties management improvement, expansion of activities in new production frontiers, introduction of cultivars with elevated potential production and precocious maturity cycle. Allied to these, there is a possibility of cultivation during every month of the year in various agro-ecological conditions (Popp, 2000; Pádua et. al., 2012b).

In Brazil, potato production is designated predominantly to the fresh market. Nonetheless, the change in dietary habits propels a demand for processed foods considering consumer market potential (Popp, 2000; Pádua et al., 2012a). Fried potatoes are the preferred form by Brazilians (Lopes \& Buso, 1997), with estimated consumption of 800 tons per year (Geraldini et al., 2011). According to Household Budget Surveys (HBSs), South, and Southeast inhabitants are 
the principal fried potatoes consumers, being that $31.9 \%$ of consumption occurs outside household (IBGE, 2010). Moreover, according to IBGE (2009), economic grades with superior income are the major consumers.

To succeed in both field and processing, elevated yield potential cultivars should be employed and adequate to each form and processing (Pádua et al., 2012b). Aiming to obtain superior yield and final product enhanced quality, the cultivar choice should be based on its intended use (Fontes, 2005; Pádua et al., 2012b). Thus, for fries processing is necessary utilize cultivars that have, principally, uniform shape, elevated dry matter content, and low reducing sugars percentage (Popp, 2000). Fries industrial processing in both shoestrings and chips is similar and the requirement regarding quality characteristics of raw materials in terms of color, flavor, and texture are basically the same.

As this is an elevated aggregated value product, the raw material cost is an essential factor in every processing form. It is necessary to meet both the interests of producers and processors. Producers demand inferior cost and high yield. On the other hand, processors are also interested in raw material with reduced cost, but combined with the best quality in order to achieve quality minimum standards after processing (Popp, 2000; Pádua et al., 2016). However, the relation among price, raw material, and product's quality is often not considered (Popp, 2000).

Several smaller Brazilian industries employ tubers of Agata cultivar in frying processing due to its availability and raw materials price. This is the principal potato grown in the country due to several relevant factors, such as rapid seed potatoes sprouting, vigorous plants, early cycle, and eminent productive potential, besides producing a considerable percentage of substantial tubers with a satisfactory appearance. Nonetheless, this is a cultivar recommended for cooking, and demonstrates no aptitude for frying (Pádua et al., 2016).

Cultivars with frying aptitude represent a small portion of the entire volume produced in Brazil, limiting raw materials offer suitable for industries (Berbari, 2005). This fact occurs due to potato fresh market requirements for external appearance, shape and size of the tubers. Brazilian producers prefer precocious and productive varieties intending to achieve enhanced marked competitiveness. These selection criteria restrict the number of cultivars in use, even with several national and foreign cultivars registered for cultivation in the country, especially those suitable for frying, which usually present tubers with lower appearance, prolonged vegetative cycle and inferior productivity.

In this context, productivity performance of potato cultivars introduced in Brazil, and its quality attributes for industrial processing in the shapes of shoestrings and chips were assessed intending to recommend competitive cultivars with those designated for fresh market tubers.

\section{MATERIAL AND METHODS}

Nine potato cultivars were evaluated: Agata, Almera, Arizona, and Saviola are not suitable for frying; Excelence, Fontane and Markies present dual aptitude, which signifies that those were recommended for both cooking and frying; lastly 'Caruso' and 'Destiny' are suggested for frying. Except for 'Caruso', originally from Germany, every other cultivars are of Dutch origin.

Agata, Almera, Arizona, Excelence, Saviola cultivars with early cycle, and 'Markies' with late maturation, presented elevated productivity, substantial tubers, elongated and oval shape, light yellow skin, uniform and great appearance. 'Excelence' and 'Markies' showed tubers with high dry matter content. These cultivars demonstrated dual cooking aptitude (cooking and frying) and other with inferior dry matter content and cooking capacity were not appropriate for frying (Agrico, 2013). 'Fontane', 'Destiny' and 'Caruso' demonstrated relevant productivity with oval tubers, yellow skin and tubers with elevated dry matter content. Moreover, these types are proper for frying wherein 'Fontane' has medium production cycle, great tubers and smooth skin, while 'Destiny' and 'Caruso' have early cycle, medium tubers and rough skin (Agrico 2013, Solana, 2013).

Experimental design was of randomized blocks with nine treatments and four replications. In field, the plot consisted of four furrows with 25 plants. The spacing was $0.80 \mathrm{~m}$ between furrows and $0.30 \mathrm{~m}$ between plants totaling an area of $24 \mathrm{~m}^{2}$ per plot accounting 100 useful plants. Field phase was conducted at Prata Farm, in Nova Resende, Minas Gerais State, Brazil $\left(21^{\circ} 07^{\prime} 30^{\prime} \mathrm{S}, 46^{\circ} 25^{\prime} 15^{\prime} \mathrm{W}\right.$, $1,250 \mathrm{~m}$ altitude), in the period between January and May, 2013. The experiment was performed during dry season in succession to corn crops in clayey soil, in which a preparation for planting consisted of plowing, harrowing and furrowing. Soil preparation, fertilization, and phytosanitary treatments were mechanically performed, while planting and furrows closures were manually made. Operations of ridging and topdressing were conducted in mechanized mode 30 days after planting. The harvest was accomplished 107 days after planting, when more than $80 \%$ of the plants were dead and dry.

Total and marketable production of tubers were assessed, and gathered in groups according to transversal diameter: $(\geq 85 \mathrm{~mm}=$ grade $1, \geq 45 \mathrm{~mm}$ and $<85 \mathrm{~mm}=$ grade $2 ; \geq 33 \mathrm{~mm}$ and $<45 \mathrm{~mm}=$ grade 3 ; and $<33 \mathrm{~mm}=$ grade 4) (BRASIL, 1995). Tubers from grades 1 and 2 were considered large, while grades 3 and 4 were classified as medium and tiny respectively.

The processing (Figure 1) and laboratorial evaluations were performed in Department of Agribusiness, Food, and Nutrition of Fruits and Vegetables Laboratory of ESALQ-USP. The dry matter content was determined gravimetrically according to AOAC (1995) and reducing sugar content was extracted by Yoshida (1972) method, quantified by Somogy method adapted by Nelson (1944) and expressed in wet basis percentage. Frying yield was defined according to a method cited by Paschoalino et al. (1975), adapted for potato processing for shoestring and chips shapes. The oil content was 
determined following AOAC (1995) method. Pulp mean color after frying was established by visual comparison method according to color scale and interpretation adopted by North Americans industries (USDA, 1988). The results were statistically analyzed using analysis of variance (ANOVA) and the means were compared by Tukey test at $5 \%$ of probability. Principal component analysis (PCA) was also carried out aiming to characterize cultivars and observe its correlations with analyzed attributes.

\section{RESULTS AND DISCUSSION}

Classification of harvested tubers aims to standardize these by size (larger diameter), reduce losses and provide competitive prices (Ceasaminas, 2015). Table 1 presents results referring to tubers production of the nine evaluated cultivars. Concerning total production, 'Arizona' and 'Caruso' were the most productive. Total production reflects the varieties productive potential on tested environment. Considering the productive means over $24 \mathrm{t} / \mathrm{ha}$, it can be considered that vast majority of tested cultivars have productive potential in Brazilian agro ecological conditions, as the national production average is 28.4 $\mathrm{t} / \mathrm{ha}$ (IBGE, 2015).

On the other hand, marketable tubers production that brings together grades with highest market value, 'Arizona', 'Caruso', and 'Markies' were the most productive. On production grades, cv. Saviola stood out due to large tubers production not differing from 'Arizona', 'Excelence', 'Markies' and 'Agata' (Table 1). The tubers size is a characteristic tightly linked with cultivar genetic constitution, however, this can be influenced by environmental conditions and, principally, by crops management (Pádua et al., 2012b). These characteristics could be an explanation for observed variation on tubers size among the tested cultivars, wherein each cultivar concentrated the production in a determined grade size. Although majority of cultivars exhibit superior tubers concentration in large grades, Caruso cultivar staged
Table 1. Total and marketable yield of potatoes, and tuber size grades ( $\mathrm{t} / \mathrm{ha}$ ) \{produtividade total e comercial de batata e classificação dos tubérculos por tamanho $(\mathrm{t} / \mathrm{ha})\}$. Piracicaba, ESALQ, 2013.

\begin{tabular}{lcrrrr}
\hline \multirow{2}{*}{ Cultivars } & Total tubers & \multicolumn{5}{c}{ Marketable tubers production (t/ha) } \\
\cline { 3 - 7 } & production (t/ha) & Large & Medium & Tiny & Total \\
\hline Arizona & $34.51 \mathrm{a}$ & $18.48 \mathrm{ab}$ & $11.63 \mathrm{~b}$ & $2.19 \mathrm{bc}$ & $32.31 \mathrm{a}$ \\
Destiny & $26.51 \mathrm{ab}$ & $9.22 \mathrm{~cd}$ & $13.22 \mathrm{~b}$ & $2.03 \mathrm{bc}$ & $24.47 \mathrm{ab}$ \\
Excelence & $25.83 \mathrm{ab}$ & $15.07 \mathrm{abc}$ & $8.86 \mathrm{bc}$ & $0.88 \mathrm{c}$ & $24.95 \mathrm{ab}$ \\
Saviola & $27.07 \mathrm{ab}$ & $19.37 \mathrm{a}$ & $6.12 \mathrm{c}$ & $1.08 \mathrm{c}$ & $26.56 \mathrm{ab}$ \\
Agata & $30.34 \mathrm{ab}$ & $13.27 \mathrm{abc}$ & $11.32 \mathrm{~b}$ & $3.06 \mathrm{~b}$ & $27.65 \mathrm{ab}$ \\
Almera & $27.93 \mathrm{ab}$ & $12.46 \mathrm{bc}$ & $8.31 \mathrm{bc}$ & $3.71 \mathrm{~b}$ & $24.49 \mathrm{ab}$ \\
Fontane & $22.83 \mathrm{~b}$ & $6.17 \mathrm{de}$ & $10.09 \mathrm{bc}$ & $3.29 \mathrm{~b}$ & $19.55 \mathrm{~b}$ \\
Markies & $31.97 \mathrm{ab}$ & $15.73 \mathrm{ab}$ & $10.35 \mathrm{bc}$ & $2.94 \mathrm{~b}$ & $29.03 \mathrm{a}$ \\
Caruso & $36.12 \mathrm{a}$ & $2.12 \mathrm{e}$ & $21.06 \mathrm{a}$ & $6.47 \mathrm{a}$ & $29.65 \mathrm{a}$ \\
\hline CV $(\%)$ & 15.87 & 20.81 & 18.39 & 26.84 & 13.28 \\
Total mean & 29.37 & 12.44 & 11.21 & 2.85 & 26.51 \\
\hline
\end{tabular}

Means followed by the same letter in each column do not differ by Tukey test at $5 \%$ level of probability (medias seguidas por letras iguais na coluna não diferem pelo teste de Tukey,5\%).

Table 2. Quality parameters of nine potato cultivars after processing (parâmetros de qualidade de nove cultivares de batata após processamento). Piracicaba, ESALQ, 2013.

\begin{tabular}{|c|c|c|c|c|}
\hline \multirow{2}{*}{ Cultivars } & Dry matter* & $\begin{array}{c}\text { Reducing } \\
\text { sugars* }\end{array}$ & \multicolumn{2}{|c|}{ Fries color** } \\
\hline & \multicolumn{2}{|c|}{$(\%)$} & Shoestring* & Chips* \\
\hline Arizona & $16.19 \mathrm{~cd}$ & $0.2876 \quad \mathrm{a}$ & $3.6 \mathrm{~b}$ & $4.0 \mathrm{a}$ \\
\hline Destiny & $21.61 \mathrm{~b}$ & $0.0224 \mathrm{~d}$ & $0.1 \mathrm{f}$ & $1.9 \mathrm{c}$ \\
\hline Excelence & $17.56 \mathrm{~cd}$ & $0.0244 \mathrm{~d}$ & $0.0 \mathrm{f}$ & $1.9 \mathrm{c}$ \\
\hline Saviola & $16.02 \mathrm{~cd}$ & $0.0858 \mathrm{c}$ & $4.0 \mathrm{a}$ & $3.9 \mathrm{a}$ \\
\hline Agata & $15.07 \mathrm{~d}$ & $0.0298 \mathrm{~d}$ & $2.8 \mathrm{c}$ & $4.0 \mathrm{a}$ \\
\hline Almera & $11.01 \mathrm{e}$ & $0.2032 \mathrm{~b}$ & $4.0 \mathrm{a}$ & $3.0 \mathrm{~b}$ \\
\hline Fontane & $18.82 \mathrm{bc}$ & $0.0087 \mathrm{~d}$ & $1.0 \mathrm{e}$ & $0.9 \mathrm{~d}$ \\
\hline Markies & $17.39 \mathrm{~cd}$ & $0.0077 \mathrm{e}$ & $1.0 \mathrm{e}$ & $2.0 \mathrm{c}$ \\
\hline Caruso & $23.16 \mathrm{a}$ & $0.0198 \quad \mathrm{e}$ & $2.0 \mathrm{~d}$ & $1.0 \mathrm{~d}$ \\
\hline CV (\%) & 7.95 & 6.86 & 13.27 & 5.42 \\
\hline Overall Mean & 17.43 & 0.0766 & 2.07 & 2.52 \\
\hline \multirow{2}{*}{ Cultivars } & \multicolumn{2}{|c|}{ Frying yield (\%) } & \multicolumn{2}{|c|}{ Fat absorbtion (\%) } \\
\hline & Shoestring* & Chips* & Shoestring* & Chips* \\
\hline Arizona & $19.20 \mathrm{bc}$ & 20.16 bc & $48.90 \quad a b c$ & $47.84 \mathrm{ab}$ \\
\hline Destiny & $26.63 \mathrm{ab}$ & $25.36 \mathrm{ab}$ & $46.32 \mathrm{c}$ & $34.58 \mathrm{~d}$ \\
\hline Excelence & $23.80 \mathrm{ab}$ & $23.68 \mathrm{bc}$ & $49.01 \mathrm{abc}$ & $42.55 \mathrm{bc}$ \\
\hline Saviola & $22.80 \mathrm{abc}$ & $22.76 \mathrm{bc}$ & $48.26 \mathrm{abc}$ & 54.96 a \\
\hline Agata & $22.09 \mathrm{abc}$ & $22.51 \mathrm{bc}$ & $51.66 \mathrm{ab}$ & $41.68 \mathrm{bc}$ \\
\hline Almera & $13.48 \mathrm{c}$ & $13.76 \mathrm{~d}$ & $52.22 \mathrm{a}$ & $43.96 \mathrm{bc}$ \\
\hline Fontane & $18.41 \mathrm{bc}$ & $19.16 \mathrm{~cd}$ & $45.88 \mathrm{~cd}$ & $40.62 \mathrm{~cd}$ \\
\hline Markies & $23.10 \mathrm{abc}$ & $24.94 \mathrm{ab}$ & $47.85 \mathrm{bc}$ & $38.17 \mathrm{~cd}$ \\
\hline Caruso & $31.18 \mathrm{a}$ & $29.24 \quad \mathrm{a}$ & $42.21 \mathrm{~d}$ & $38.39 \mathrm{~cd}$ \\
\hline $\mathrm{CV}(\%)$ & 18.76 & 10.14 & 1.46 & 2.79 \\
\hline Total mean & 22.29 & 22.39 & 48.03 & 42.53 \\
\hline
\end{tabular}

Means followed by the same letter in each column do not differ by Tukey test at $5 \%$ level of probability (medias seguidas por letras iguais na coluna não diferem pelo teste de Tukey,5\%). $*$ Transformed data. ${ }^{*}$ Scale: $0=$ very light yellow (amarelo muito claro); $1=$ light yellow (amarelo claro); $2=$ golden yellow (amarelo ouro); $3=$ yellow with brown spots (amarelo com manchas marrons); $4=$ predominantly brown color (cor predominantemente marron). 
a production concentrated on tubers of medium grade according to this cultivar standardize characteristic as stated by Solana (2013). 'Excelence' and 'Saviola' were the varieties that presented lower production of tiny tubers.

Large tubers grade is the most prized in fresh tubers market due to peeling facilitation on domestic processing. For chips frying process, the round or ovalround form is preferable besides larger size, to enable obtaining elevated yield of slices within commercial standards (Pádua et al., 2012b). Cultivar Destiny was the one that best approaches these requirements.

For shoestring potato production, the tubers size is not the most important characteristic, but the uniformity within the batch, which aims to provide improved efficiency in peeling and cutting process. Therefore, this is essential to obtain equal sized fillets that will result in a better and uniform frying (Pádua et al., 2012b). Thus, cvs. Caruso, Destiny and Fontane reveal themselves suitable for shoestrings production due to the presence of oval tubers, elevated concentration of average-sized tubers, and considerable size uniformity.

Overall mean for dry matter content obtained in this work was $17.43 \%$ (Table 2), which is in accordance with Brazilian Food Composition Table (TACO). This table describes that planted cultivars in Brazilian conditions achieve, in average, $17.1 \%$ of dry matter (Unicamp, 2006). Cultivars Caruso, Destiny, Excelence, Fontane, and Markies presented dry matter content over 17\% (Table 2), which is close to the demands required for shoestring production that according to Gomes et al. (2005) should be superior to $18 \%$. Vendrusco \& Zorzella (2002) also pointed out that even with inferior dry matter content, several cultivars can be employed in fries industry with the condition that meets other frying quality attributes, which are color, oil residual content, taste, crispness and yield after processing. It is worth highlight Caruso and Destiny cultivars that presented dry matter content higher than $20 \%$ and comply, therefore, the requirements for the production of chips potato (Pádua et al., 2012b).

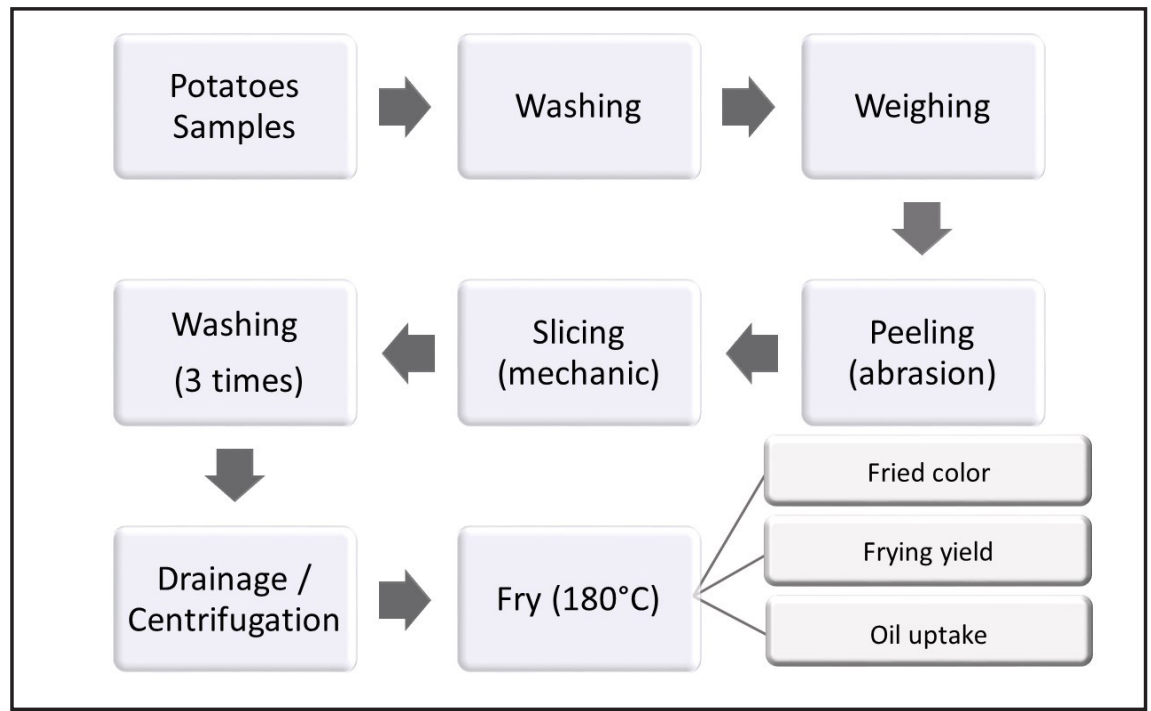

Figure 1. Flowchart of laboratory evaluations and processing of potatoes as shoestrings and chips (segmentos em laboratório, da avaliação e processamento de batata para chips e batata palha). Piracicaba, ESALQ, 2013.

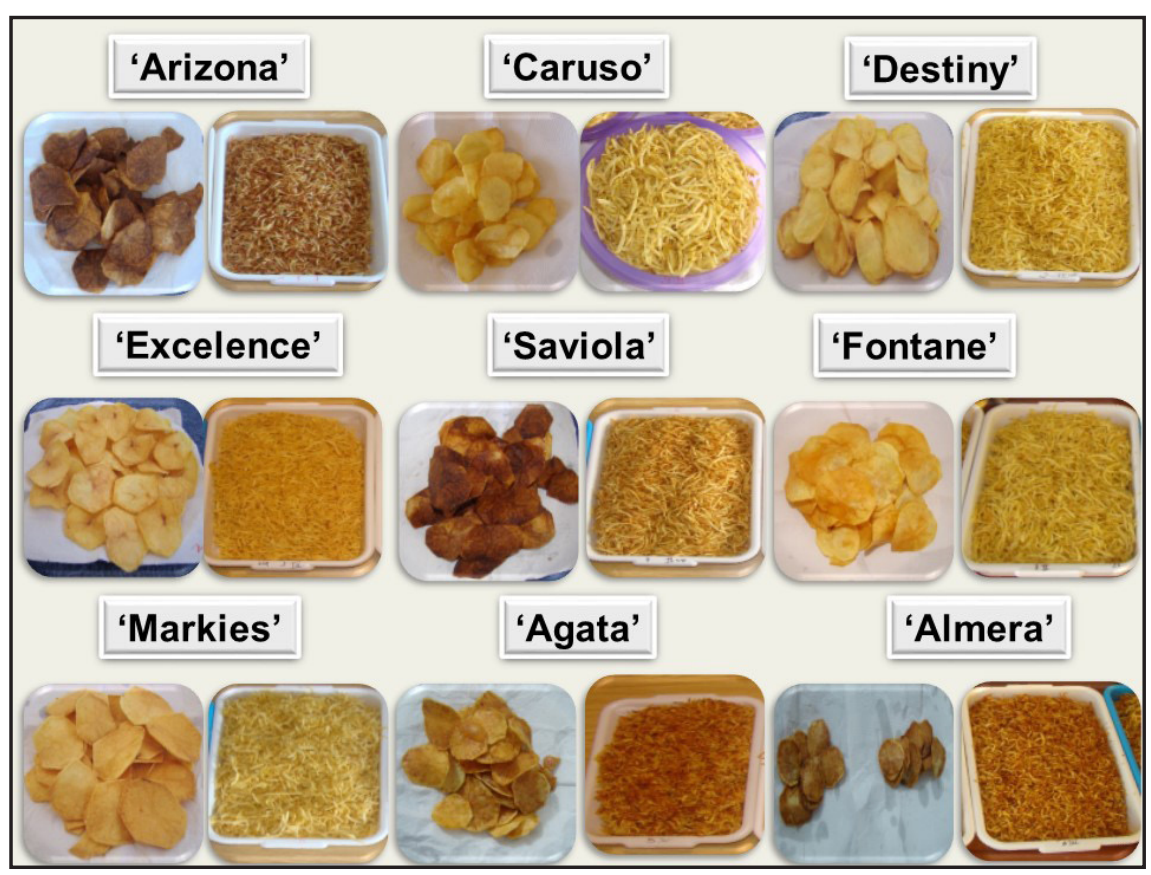

Figure 2. Shoestring potatoes and potato chips colors observed in the tested cultivars (cores de batata palha e de batata chips observadas nas cultivares testadas). Piracicaba, ESALQ, 2013.

Dry matter content and reducing sugars can be considered, among others, the most limiting processing factors, considering that they are essential in fat absorption, final product appearance and texture. Reducing sugars in tubers react with proteins and free amino acids in cytoplasm, through Maillard reaction, during frying process producing brown colored pigments with bitter taste that depreciate the final product (Pádua et al., 2012b). Therefore, potato cultivars indicated to frying form processing should present reducing sugars content inferior to $0.035 \%$ of fresh matter (Stark et al., 2003).

'Caruso' and 'Markies' exhibit inferior content of reducing sugars, which is a notable factor to be considered in recommendation of these cvs. for frying, knowing that lower contents will permit a lighter color and a more pleasant flavor on final product. On the other hand, 'Destiny', 'Excelence', 


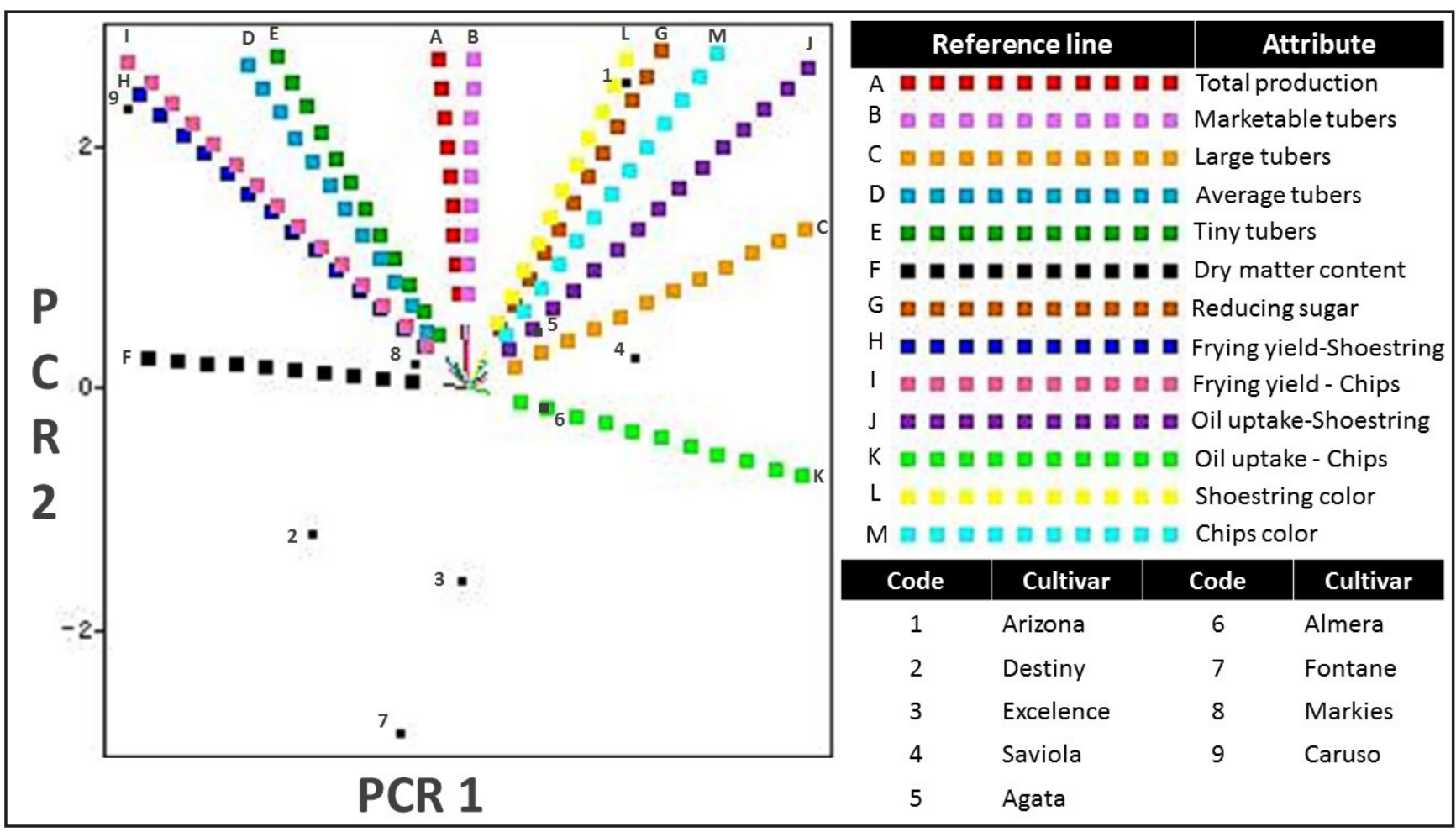

Figure 3. Biplot chart of principal components analysis of potato cultivars and its attributes (tabela biplot dos principais componentes e para análise de cvs. de batata e seus atributos). Piracicaba, ESALQ, 2013.

'Fontane', and 'Agata' have shown intermediary content. Considering that 'Agata' presented inferior dry matter content, 'Destiny', 'Excelence', and 'Fontane' could be a more appropriated option to substitute Agata in frying process for industries that use them. 'Saviola', 'Arizona' and 'Almera' displayed superior reducing sugars content, therefore, should not be utilized in frying process due to both darkening and bitter taste of final product (Table 2).

The fat absorption in potato frying process is of about $35 \%$ including that present on the surface, which penetrates into pulp after processes completion (Pedreschi et al., 2008). Dry matter content is inversely proportional to potato water content. This affects absorbed fat quantity due superior water absorption during heating and water evaporation. Besides dry matter content, this absorption is related to the type of potato cut. In this case, shoestring potato presents greater absorption than chips due to superior exposed surface.

According to TACO, average fat absorption of potatoes is $41 \%$ for shoestring and $36 \%$ for chips (Unicamp, 2006). Absorbed fat quantity is extremely trivial for final products. Elevated fat contents lead to drenched fries conferring inferior crispness, taste alteration, quality and appearance damaging as well as increasing production cost (Grizotto, 2005). Caruso and Destiny cvs. demonstrated inferior fat absorption when fried as shoestring, and chips respectively (Table 2). Comparing TACO (Unicamp, 2006) with obtained values of 'Caruso', 'Destiny', 'Fontane', and 'Markies' (Table 2) it can be observed that these cultivars could be recommended for chips, and of those, only Caruso would be indicated for shoestrings.

'Caruso' provided the best frying yield in both shapes. In contrast, 'Almera' presented the lowest yield in both frying forms (Table 2) highlighting that this cultivar was not suitable for this processing type.

Besides the attributes already evaluated, processed potato acceptance depends on, principally, final product coloration. This attribute is considered the most important in fried potato quality. Moreover, this characteristic is essential for consumer's acceptance. According to Tocchini \& Mercadante
(2001), in food evaluation, the visual impact caused by its color overlaps other attributes, highlighting that this feature is one of the most important for products commercialization being the first criterion for production acceptance and rejection. Therefore, its evaluation is extremely important for industrial processing. Grizotto (2005) pointed out that ideal fries color varies from light yellow to golden yellow without achieving brown tonality and absence of dark spots or lines.

Fried potato coloration varied from extremely light yellow and predominantly brown (Table 2; Figure $2)$. Destiny, Excelence, Fontane and Markies cvs. exhibit light color after fried as shoestrings and chips, which lead to a notable appearance final product. The other cultivars presented yellow coloration with brown parts varying from brow dots to predominantly brown, being unsuited for both processing forms.

Through principal components analysis (Figure 3), a relation among analysed attributes can be precisely assessed. Attributes reference lines reveal that total and marketable 
production present extremely elevated correlation; therefore, one is conditioned to the other. In grades stratification it is possible to infer that large, average size, and tiny tubers present high negative correlation, which means that, when an attribute increases, the other decreases accordingly.

Considering processing linked attributes, it is observed that dry matter content is associated with fat absorption and frying yield. The highest correlation was between fat absorption and shoestring processing, and it is noteworthy to emphasize that this correlation is inverse: the higher the tubers dry matter content, inferior is the fat amount absorbed by potato fries. In contrast, frying yield association is elevated and positive in both processing forms. Thus, an inference is plausible indicating that frying yield will be superior in accordance with dry matter content increase while fat absorption will be inferior (less drenching). In consequence, a crisp final product would be obtained.

A high correlation between reducing sugars content and potato fries color, which means that the higher the content, higher color scale score would be, that is, the fried potato would be darker. Thus, in overall evaluation of attributes quality is desirable that potatoes destined for frying processing present elevated dry matter content and reducing sugars low content in order to provide satisfactory performance in frying process as well as crispier potatoes with clear coloration and attractive to consumer.

When associated, attributes for components formation can infer that first principal component (PCR1) represents production attributes, and the second (PCR2) quality features (Figure 3). Therefore, when assessed cultivars are related to attributes present in principal components, the varieties can be characterized globally. This information is corroborated by variance analysis and significance test presented in Tables 1 and 2.

'Arizona' and 'Saviola' presented elevated total and commercial production of large tubers grade (Table 1). When considering attributes linked to processing, 'Arizona' exhibit inferior dry matter content, while 'Saviola' and 'Arizona' displayed intermediary content and elevated reducing sugars (Table 2). Both cultivars produced dark color potato fries (brown color predominance) as well as eminent fat absorption for both shoestrings and chips (Table 2). This features set indicates that these cultivars are inapt to frying and more appropriate to fresh tubers market.

Destiny cv. presented lower total and commercial production, intermediary tubers production of tiny and average size with little large size production (Table 1). Dry matter content was elevated and reducing sugars were depleted. After processing, the cultivar provided average yield in high frying, high fat absorption for shoestrings and decreased for chips (probably due to the type of cut), shoestring potato with extremely light yellow coloration and chips nearby golden yellow tonality (Table 2, Figure 2 and 3). In general, 'Destiny' demonstrated a set of desirable attributes for processing, which leads to a recommendation for frying of both shoestring and chips.

When the production attributes were evaluated, 'Excelence' presented intermediary values among the other cultivars for total and commercial production, large and average size tubers, and inferior tiny tubers production (Table 1). Dry matter content and reducing sugars content were significantly inferior. In the same matter that production attributes, Excelence came up with intermediary values for frying yield, fat absorption and shoestring and chips with light coloration in both frying conditions (Table 2, Figure 2 and 3).

'Caruso' brought forward elevated total and marketable production. In grades, it stood out with the highest production of tiny and average sized tubers and inferior for large tubers (Table 1). Its dry matter content was the highest among every cultivar and the reducing sugar content the minor. After fried, presented elevated yield in both processing forms, decreased fat absorption as shoestrings and in average as chips, potatoes with light coloring in both frying forms (Table 2, Figure 2 and 3). This attributes set highlights $\mathrm{cv}$. Caruso as suitable for shoestring and chips frying.

'Agata' and 'Almera' exhibited intermediary values for productive performance, large tubers production (Table 1) and frying yield (Table 2). Dry matter content was hereinafter, both reducing sugar content and fat absorption were high, while shoestring potato, and chips presented dark coloration (Table 2). This attribute set reaffirm that these cultivars are inapt for frying and apt for fresh market.

'Markies' and 'Fontane' presented intermediary values for productive yield, large tubers production (Table 1) and dry matter content (Table 2). They exhibit lowered reducing sugars and low fat absorbance. Frying yield was elevated for 'Markies' and low for 'Fontane'. Both originated shoestring and chips potatoes with light coloration (Table 2, Figure 2 and 3). These results point out 'Markies' and 'Fontane' with competitive potential to substitute 'Agata', 'Arizona', 'Almera', and 'Saviola' for fried potatoes processing.

Considering the requirements for frying processing, it is concluded that cvs. Destiny, Excelence, and Caruso presented superior productive efficiency of raw material with aptitude to fry in shoestring shape, with 'Destiny' being also suitable for chips production. Markies and Excelence, which exhibit tubers with elongated oval shape and great appearance, showed suitability for multi-purpose, that is, aptitude to frying processing and for fresh market, while 'Fontane' proved to be competitive with 'Agata' in fries production. The other cultivars showed no aptitude for frying processing. However, cvs. Arizona and Saviola meet tubers standards for fresh market conditions due to tubers appearance and productive performance similarly to 'Agata' and 'Almera'.

\section{ACKNOWLEDGEMENTS}

To CNPq for granting scholarship to the first author; FAPEMIG by research support grant; AGRICO U.A. and Margossian Seeds Ltda., for the seed 
tubers and structure; FAPESP for the research financial support.

\section{REFERENCES}

AGRICO. 2013. Produtos e serviços: variedades de batata. Disponível em <http://www. agrico.nl/en/products-and-services/potatovarieties/>. Acessado em 11 de novembro de 2015.

AOAC. 1995. Association of Official Analytical Chemistry. Official methods of analysis. $16^{\text {th }}$ ed. Arlington: AOAC International. 1025p.

BERBARI, S. 2005. Processamento e rendimento industrial da batata pré-frita congelada. In: SEMINÁRIO MINEIRO SOBRE PROCESSAMENTO DE BATATAS. Anais... Pouso Alegre: ABASMIG.

BRASIL. 1995. Ministério da Agricultura, Pecuária e Abastecimento. Portaria $n^{\circ} 69$, de 21 de fevereiro de 1995. Dispõe sobre norma de identidade, qualidade, acondicionamento, e embalagens de batata para fins de comercialização. Diário Oficial da República Federativa do Brasil. Brasília.

CEASAMINAS. Agroqualidade. 2015, 12 março. Disponível em $<$ http://www.ceasaminas.com. br/agroqualidade/batata.asp $>$. Acessado em 29 de abril de 2016.

FONTES, PCR. 2005. Cultura da batata. In: FONTES, PCR (ed). Olericultura: teoria e prática. Viçosa: SUPREMA. cap. 21, p.323343.

GERALDINI, F; JULÃO, L; BORGATO, E. 2011. Procuram-se agroindústrias. HotifrutiBrasil. 10: 8-13.

GOMES, CAO; FREIRE JUNIOR, M; ALVARENGA, ALB; MACHADO, LP. 2005. Batata frita. Embrapa: Coleção Agroindústria Familiar - Agregando valor à pequena produção. Brasília: Embrapa Informação tecnológica. $42 \mathrm{p}$.
GRIZOTTO, RK. 2005. Processamento da batata chips e palha. In: SEMINÁRIO MINEIRO SOBRE PROCESSAMENTO DE BATATAS. Anais... Pouso Alegre: ABASMIG. Disponível em: <http://www.abbabatatabrasileira.com.br/ brasil_eventos_minas2005.htm $>$.

IBGE 2010. Instituto Brasileiro de Geografia e Estatística. Pesquisa de orçamentos familiares 2008-2009: aquisição alimentar domiciliar per capita. Rio de Janeiro: IBGE, 284p.

IBGE 2015. Instituto Brasileiro de Geografia e Estatística. Levantamento sistemático da produção agrícola. 2015. Disponível em: <http://www.ibge.gov.br/home/ estatistica/pesquisas/pesquisa_resultados. php? indicador $=1 \&$ id_pesquisa $=15>$.

LOPES, CA; BUSO, JA. 1997. Cultivo da batata (Solanum tuberosum L.). In: LOPES CA; BUSO, JA (eds). Cultivo da batata (Solanum tuberosum L.). Brasília: EMBRAPA, CNPH, 1997. 35p. (Instruções Técnicas, 8).

NELSON, N. 1944. A photometric adaptation of the Somogyi method for the determination of glucose. Journal of Biological Chemistry. 153: 375-380.

PÁDUA, JG; ARAÚJO, TH; CARMO, EL; MARGOSSIAN, PL; PEREIRA, SG. 2012a. Cultivares de batata para o mercado segmentado. Revista Raízes e Amidos Tropicais 8: 36-46.

PÁDUA, JG; ARAÚJO, TH; MESQUITA, H; GONÇALVES, ED. 2016. Produção de batata-palha no Sul de Minas - oportunidades e desafios. Circular Técnica da EPAMIG. 236: 1-6.

PÁDUA, JG; MESQUITA, HA; CARMO, EL; ARAÚJO, TH; DUARTE, HSS. $2012 \mathrm{~b}$. Cultivares: a escolha correta faz a diferença. Informe Agropecuário 33: 30-39.

PASCHOALINO, JE; FERREIRA, VLP; POMPEU, RM. 1975. Aptidão das variedades de batatinha Bintje e Radosa para o processamento de fritas à francesa congeladas e purê congelado. Coletânea do Instituto de
Tecnologia de Alimentos. 6: 431-444.

PEDRESCHI, F; COCIO, C; MOYANO, P; TRONCOSO, E. 2008. Oil distribution in potato slices during frying. Journal of Food Engineering. 87: 200-212.

POPP, P. 2000. Industrialização da batata no Brasil. In: WORKSHOP BRASILEIRO DE PESQUISA EM MELHORAMENTO DE BATATA, 1996, Londrina, PR. Anais... Brasília: EMBRAPA Hortaliças. p.35.

SOLANA. 2013. Solana seeds - Caruso. Disponível em: <http://www.solana.de/ kartoffelsorten-detail_en/items/caruso.html>. Acessado em 10 de fevereiro de 2013.

STARK, JC; OLSEN, N; KLEINKOPF, GE; LOVE, SL. 2003. Tuber quality. In: STARK ,JC; LOVE, SL (eds). Potato production systems. Aberdeen: University of Idaho. p.329-343.

TOCCHINI, L; MERCADANTE, AZ. 2001. Extração e determinação, por CLAE, de bixina e norbixina em coloríficos. Ciência Tecnologia de Alimentos. 21: 310-313.

UNICAMP. 2006. Tabela Brasileira de Composição de Alimentos. Universidade Estadual de Campinas. 2ed. Campinas. Disponível em: <http://www.unicamp.br/nepa/ taco/tabela.php? ativo=tabela\&PHPSESSID $=8 \mathrm{ab} 54 \mathrm{bcd} 9586 \mathrm{~d} 213$ 1bf21fb707820c09>. Acessado em 27 de outubro de 2013.

USDA 1988. United States Department of Agriculture. Color standards for frozen french fried potatoes. Baltimore: Munsel Color Company, p.1. Folder.

VENDRUSCO, JLS; ZORZELLA, CA. 2002. Processamento de batata (Solanum tuberosum L.): fritura. Pelotas: EMBRAPA Clima Temperado. $15 \mathrm{p}$.

YOSHIDA, S; FORNO, DA; COCK, JH; GOMES, KA. 1972. Determination of sugar and starch in plant tissue. In: YOSHIDA, S. FORNO, DA; COCK, JH; GOMES, KA (eds). The glycoside hydrolases: laboratory manual for physiological studies of rice. $2^{\text {nd }}$ ed. Manila: International Rice Research Institute. p. 38-41. 